\title{
DIPLOZOON HOMOIN (DISCOCOTYLIDAE, MONOGENOIDEA), A NEW PARASITE IN POND-REARED HYPOPHTHALMICHTHYS MOLITRIX
}

\author{
Z. LUCKÝ \\ Department of Diseases of Poultry, Fish, Game and Bee, University of Veterinary Science, \\ 61242 Brno
}

Received April 12, 1980

\begin{abstract}
Lucký Z.: Diplozoon homoin (Discocotylidae, Monogenoidea), a New Parasite in Pond-reared Hypophthalmichthys molitrix. Acta vet. Brno, 50, 1981: 237-244.

Examination of health status of silver carp (Hypophthalmichthys molitrix) fry from the State Fishery, Pohořelice, revealed repeatedly infestation with the monogenean trematode of the genus Diplozoon.

Examination of 2-month-old fry, collected on August 10, 1976, revealed a $20 \%$ extensity of 1 adult worm or larva. Examination performed one month later (September 6, 1976), however, showed an extensity of $70 \%$ and intensity of 2.5 worms. The maximum invasion intensity found was 7 parasites.

The study presents the species determination of the material gathered from the gills of the invaded fish fry. The metrical characteristics of the trematode are as follows: total length $2.6-3.1 \mathrm{~mm}$, length of the anterior part of the body 1.7 to $2.08 \mathrm{~mm}$, the posterior part was $0.78-1.4 \mathrm{~mm}$ long. The ratio of the anterior and posterior parts was $2-2.17: 1$. The clamps were $0.099-0.156 \mathrm{~mm}$ wide. The handle of the additional hooklets was $0.041-0.047 \mathrm{~mm}$ long, the hooklet proper was 0.018 to $0.022 \mathrm{~mm}$ long, the spike was $0.006 \mathrm{~mm}$ long. All specimens belong to the species Diplozoon homoin which is a frequent parasite of several cyprinid fish species (Rutilus rutilus, Carassius carassius, Leuciscus cephalus, Alburnus alburnus).

Hypophthalmichthys molitrix is a new host of the monogenean trematode Diplozoon homoin. The above-mentioned cyprinid fish present in ponds and supplying water sources should be regarded as reservoirs of the parasite.
\end{abstract}

Gills, parasite, morphology, reservoir fish.

Regular examination of health status of herbivorous fish reared in the fish culture unit (State Fishery, Pohořelice), performed in 1976, repeatedly revealed mild to heavier infestation of the silver carp fry with the monogenean trematodes of the genus Diplozoon.

\section{Materials and Methods}

The examinations were conducted on silver carp fry from the pond "Mírový" of the State Fishery, Pohořelice, after artificial spawning made between June 10 and 20, 1976. The fry was transferred into the nursery pond to be grown in monoculture. Prior to stocking, the bottom of the pond was disinfected. The nursery pond was supplied with water from the river Jihlava. There were no barriers or prefiltering so that uncontrolled various fish species were living in the system.

The first silver carp fry were fished for parasitological examination on August 10, 1976, the second sampling was done on September 6,1976 before transfer of the fish into storage ponds.

From both fishings, 30 fry were examined for freedom from parasites by means of the complete parasitological dissection. All gill arches were examined thouroughly, the monogenean trematodes of the genus Diplozoon were collected, spread on the glass in one drop of water, gently pressed by the cover slide, fixed in glycerine-alcohol, transferred into clean glycerine. The cover slide was 
then framed by varnish. The metrical data presented in this work were collected from the fixed parasites.

The infestation was evaluated in terms of extensity (i. e. percentage of silver carp infested) and intensity (parasite number in individual infested silver carp).

\section{Results and Discussion}

The first collection of silver carp comprised fry about 2-month-old and 36 to $54 \mathrm{~mm}$ long (mean $49 \mathrm{~mm}$ ). Monogenean trematodes of the genus Diplozoon were found in 6 specimens ( $20 \%$ extensity). Two fish were parasitized by one mature specimen and in 4 fish the larval stages (diporpa) were found.

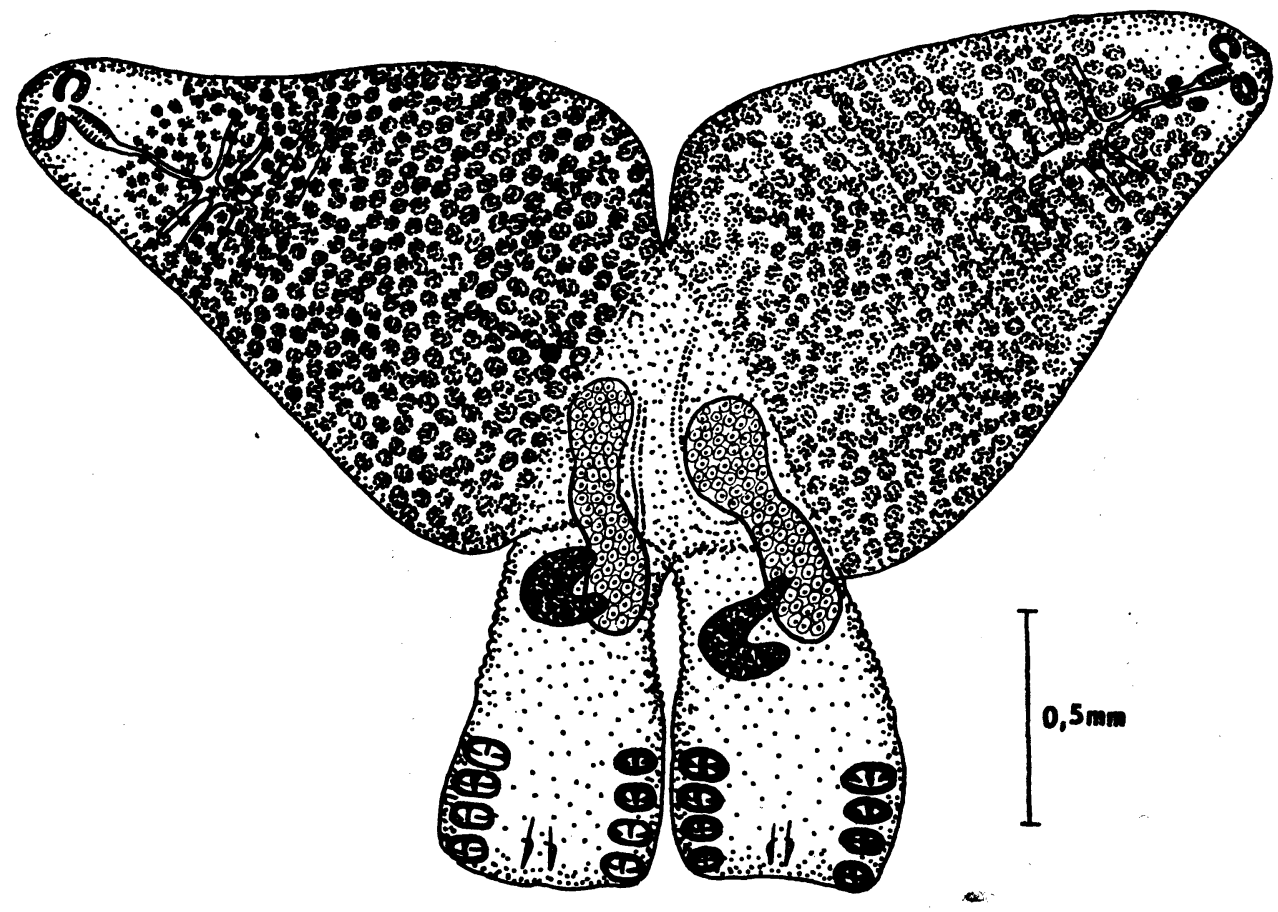

Fig. 1. Diplozoon homoin from the gills of the silver carp (adult individuals grown together)

The second fishing (about one month later) revealed almost completely impaired growth of the fry caused by advanced diplostomosis of the eye lens and kryptobiosis of the gills. The fish were 3 months old and only $39-53 \mathrm{~mm}$ long (mean $45 \mathrm{~mm}$ ). The trematodes of the genus Diplozoon were found in 21 specimens (extensity $70 \%$ ). Sexually mature parasites were collected from 18 fish (extensity $60 \%$ ), larvae were found in 9 fish (extensity $30 \%$ ). Five fish were parasitized by both larval and adult trematodes. Maximum intensity with 2 larval and 5 adult flukes was found in one $\mathbf{4 0} \mathrm{mm}$ long silver carp. In fry with higher invasion intensity invariably one trematode was found on one gill arch, only in one case 2 parasites on one gill arch were detected. The remaining gill arches were free from parasites of this genus. 
Further examinations of the silver carp fry were made from 1976 to 1979 in several localities of the area and revealed no more parasites of this genus.

Results of the parasitological examinations made in 1976 are given in Table 1.

Table 1

\begin{tabular}{|c|c|c|c|c|c|c|}
\hline \multirow{2}{*}{ Date } & \multirow{2}{*}{$\begin{array}{l}\text { Number of fioh } \\
\text { examined }\end{array}$} & \multicolumn{2}{|c|}{ Size of the fish in $\mathrm{mm}$} & \multicolumn{3}{|c|}{$\begin{array}{l}\text { Trematodes of the genus } \\
\text { Diplozoon }\end{array}$} \\
\hline & & range & average & $\begin{array}{c}\text { Extensity } \\
\%\end{array}$ & $\begin{array}{r}\text { In } \\
\text { range }\end{array}$ & $\begin{array}{l}\text { ty } \\
\text { rage }\end{array}$ \\
\hline $\begin{array}{l}\text { August 10, } \\
1976 \\
\text { September 6, } \\
1976\end{array}$ & $\begin{array}{l}30 \\
30\end{array}$ & $\begin{array}{l}36-54 \\
39-53\end{array}$ & $\begin{array}{l}49 \\
45\end{array}$ & $\begin{array}{l}20 \\
70\end{array}$ & $\begin{array}{l}1-1 \\
1-7\end{array}$ & $\begin{array}{l}1 \\
2.5\end{array}$ \\
\hline
\end{tabular}

Species determination of the collected parasites was done according to the criteria presently used for the genus Diplozoon (Pejčoch 1968).

The body of the adult trematode was $2.6-3.1 \mathrm{~mm}$ long, with maximum width of $0.65-1.3 \mathrm{~mm}$, width of the haptor was 0.5 to $0.6 \mathrm{~mm}$. The anterior part of the body was $1.7-2.08 \mathrm{~mm}$ long and $0.65-1.3 \mathrm{~mm}$ wide. The posterior part was $0.78-1.4 \mathrm{~mm}$ long and 0.39 to $0.7 \mathrm{~mm}$ wide. The ratio between the anterior and posterior parts of the body was $2-2.17: 1$. Dimensions of the oral suckers were $0.049 \times 0.059-0.66 \mathrm{~mm}$, those of the oval pharynx $0.046-0.049 \times 0.066-0.067 \mathrm{~mm}$. The intestine had numerous branches sent off in its course and they were extremely deep. The caudal end of the intestine was not very clear in our fixed specimens. The reproductive tract was placed in the caudal part of the body which was folded just behind the junction. There were usually 11 to 12 folds.

The haptor was equipped with metamorphosed clamps of usual shape. The first pair of clamps was 0.099 to $0.115 \mathrm{~mm}$ wide the second pair was $0.117-0.140 \mathrm{~mm}$ wide, the third reached $0.125-0.148 \mathrm{~mm}$, and the fourth pair was $0.125-0.156 \mathrm{~mm}$ wide.

The handles of the hooklets situated between the clamps was were $0.041-0.047 \mathrm{~mm}$ long, the hooklets proper were $0.018-0.022 \mathrm{~mm}$ long, and the spikes were $0.006 \mathrm{~mm}$ long.

We give no description of the sexually mature individual, its dimensions are presented in Table 2.

Review of to date found species of the genus Diplozoon Nordmann, 1932, published by Pejčoch (1974) indicates that on the gills of the silver carp the species Diplozoon inustiatus Nagibina 1965, and Diplozoon marinae Achmerov, 1974 were described.

The species Diplozoon inustiatus described by Nagibina (1965) is characterized by a large and prominent

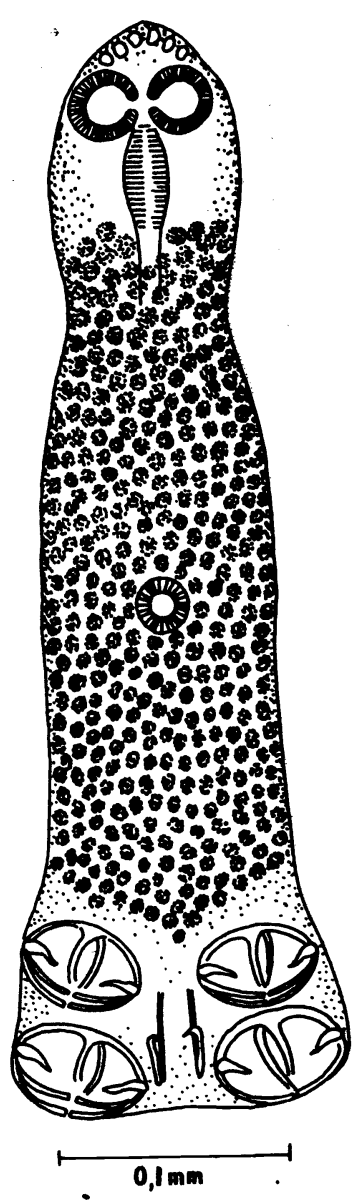

Fig. 2. Diplozoon homoin from the gills of silver carp (larva - diporpa) 


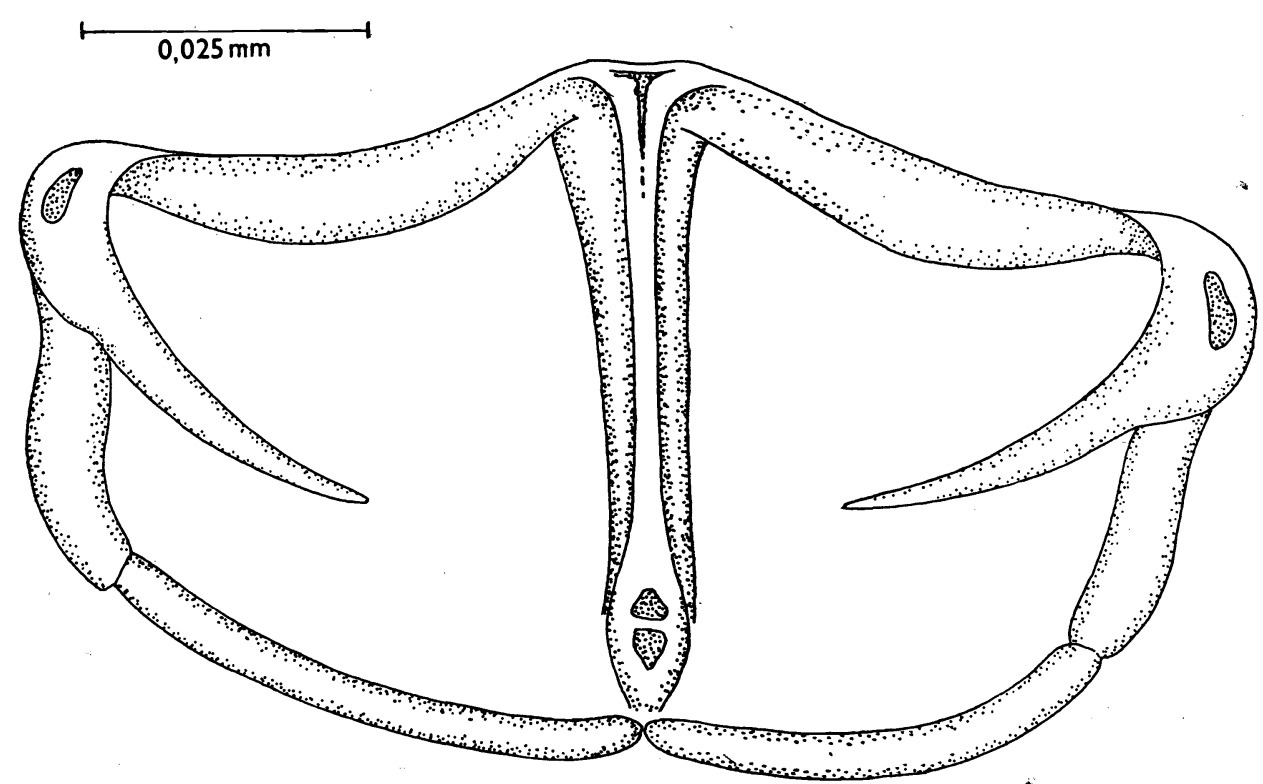

Fig. 3. Diplozoon homoin - the shape of the metamorphosed sucker of the first pair

"disc", $1.3-2.1 \mathrm{~mm}$ in diameter. The size of the parasite and the handle of the hooklets $(0.058-0.060 \mathrm{~mm})$ surpass several times that of our specimens.

The species Diplozoon marinae is described in detail by Achmerov (1974) and our specimens do not differ from this description except for the length of the handle of the hooklets which was invariably longer in our material. Maximum length of the handle described by Achmerov (1974) reached only the sizes found in the smallest individuals of our collection. However, the hooklet proper was found to be twice as long as that described by the above-mentioned author. Although according to Ergens and L o m(1970) the majority of determination cri-
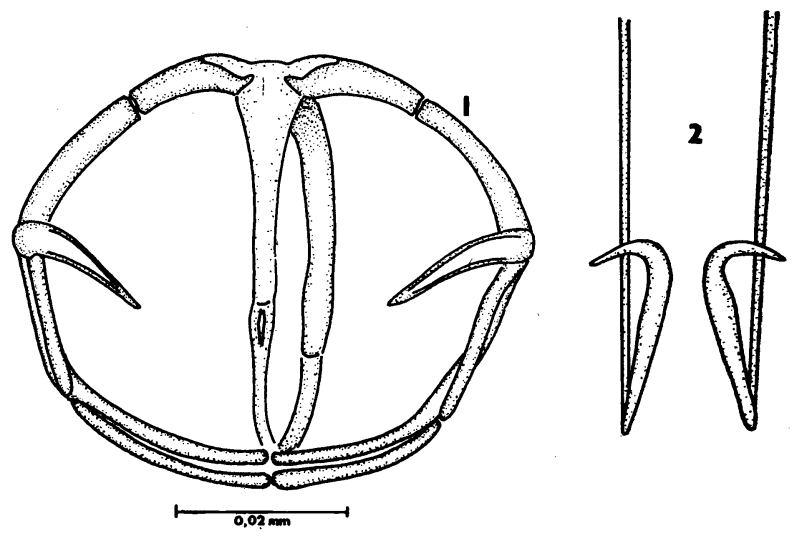

Fig. 4. Diplozoon homoin: 1 - metamorphosed sucker of the diporpa, 2 - hooklets teria employed for identification of species of the genus Diplozoon have to date no verified taxonomic value, we cannot include our specimens into the species Diplozoon marinae.

Several species of the genus Diplozoon have been found in fish from the river Danube (Pejčoch 1968). Among these, the species $D$. homoin seems to be the closest to our specimens in terms of dimensions. This conclusion is also supported by data of $\mathrm{By}-$ 


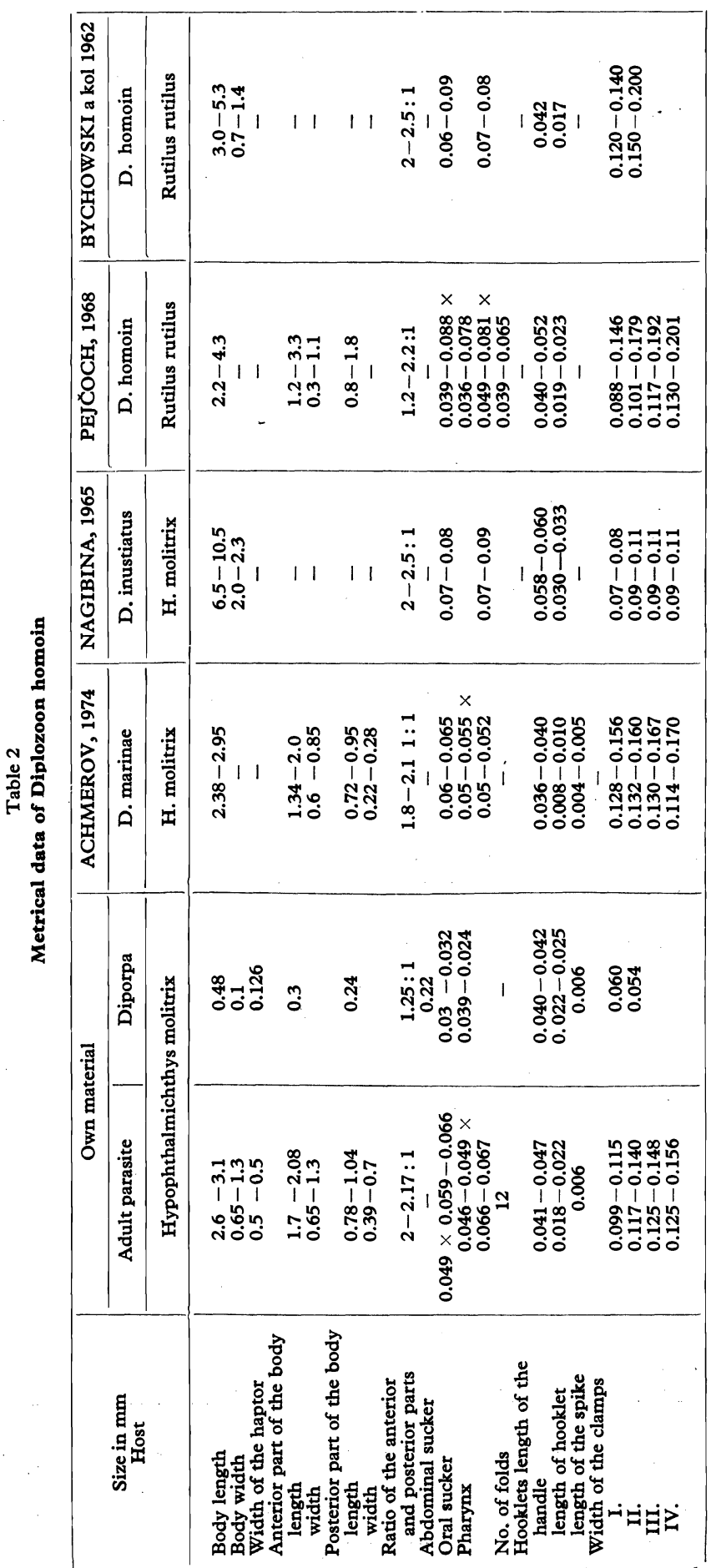




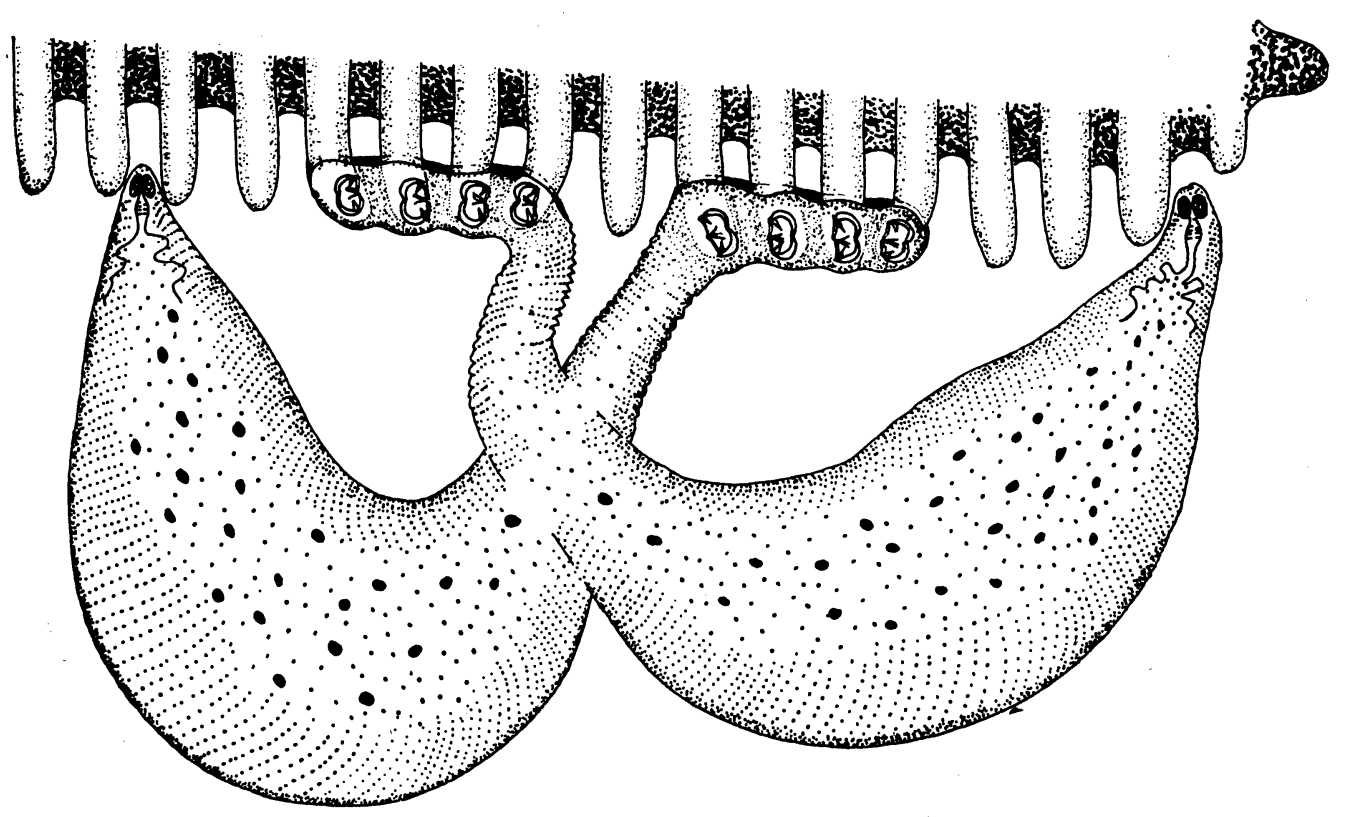

Fig. 5. The mode of fixation of the monogenean trematode Diplozoon homoin on the gill filament drawn according to real situation in situ

chowski et al. (1962), who found sizes of the handles of hooklets similar to those found in our specimens.

On the basis of our findings and data of other authors it seems correct to classify the investigated specimens as Diplozoon homoin.

Moreover, our study indicates that a detailed zoological elaboration of parasites found in acclimatized herbivorous fish is of great importance in that it may prevent incorrect conclusions concerning transmission of parasites from the basin of the river Amur or some other areas with fish importation.

The study has further shown that the monogenean trematode Diplozoon homoin parasitizing in Rutilus rutilus, Carassius carassius, Leuciscus cephalus and Alburnus alburnus has been repeatedly found also in fish from the river basin of South Moravia. However, the definitive host of the parasite is the silver carp. Only in this fish species the sexual maturation of the trematode occurs. The above-mentioned hosts of the trematode are frequent weed fish species also under fish farming conditions and they should be considered as reservoirs of the trematode for the silver carp. This herbivorous fish belongs to economically important species to which intensive veterinary care is given.

\section{Diplozoon homoin (Discocotylidae, Monogenoidea), nový cizopasník Hypophthalmichthys molitrix při rybničním odchovu}

Při sledování zdravotního stavu plůdku tolstolobika bilého (Hypophthalmichthys molitrix) v rybničních soustavách Státního rybářství - Pohořelice (povodí řeky Jihlavy) byly opakovaně na žábrách ryb zjištovány monogenetické motolice $\mathrm{z}$ rodu Diplozoon, ve slabých až středních invazích. 
Ze sledovaných lokalit bylo vyšetřeno vždy 30 kusů ryb. Vyšetřováni bylo provedeno parasitologickou pitvou ryb a zjištěné invase byly vyjádřeny absolutním počtem cizopasníků.

U vzorkủ odebraných 10 . VIII. 1976, asi dva měsíce po narození ryb, byla zjištěna extenzita výskytu $20 \%$, při intenzitě 1 dospělý červ nebo larva u jedné ryby, u vzorku odebraného 6 . IX. 1976 stoupla extenzita invazí na $70 \%$, při průměrné intenzitě 2,5 červa. Maximální intenzita byla 7 červů.

Studie se zabývá druhovou determinací dokladového materiálu s použitím současně platných kritérií pro druhové rozlišování příslušníků tohoto rodu.

Červi byli $2,6-3,1 \mathrm{~mm}$ velcí, đélka přední části měřila $1,7-2,08 \mathrm{~mm}$, zadní části $0,78-1,4 \mathrm{~mm}$. Poměr přední $\mathrm{k}$ zadní části těla byl $2-2,17: 1$. Śírka metamorfovaných př́savek měřila $0,099-0,156 \mathrm{~mm}$. Rukojet středních háčkủ je dlouhá $0,041-0,047 \mathrm{~mm}$, vlastní háček měří $0,018-0,022 \mathrm{~mm}$, délka hrotu $0,006 \mathrm{~mm}$. Po podrobném prostudování speciální literatury bylo zjištěno, že všechny dokladové exempláře patřily druhu Diplozoon homoin, který je častým cizopasníkem některých druhů kaprovitých ryb (Rutilus rutilus, Carassius carassius, Leuciscus cephalus, Alburnus alburnus).

Rybí druh Hypophthalmichthys molitrix je novým hostitelem monogenetické motolice Diplozoon homoin a uvedené kaprovité druhy ryb, pokládané v rybničních soustavách za plevelné, je třeba považovat za rezervoáry tohoto druhu cizopasníka pro chovný druh - tolstolobik bílý, který je intenzívně odchováván ve sledovaném rybářském závodè.

\section{Diplozoon homoin (Discocotylidae, Monogenoidea) новый паразит в рыбоводстве Hypophthalmichthys molitrix}

Наблюдая за состоянием здоровья мальков белого толстолобика ( $\mathrm{Hy}$. pophthalmichthys molitrix) в прудовом хозяйстве Государственного рыбоводства - Погоржелице (басейн реки Йиглавы) были повторно в жабрах рыб выявлены моногенетические двуустки рода Diplozoon, в слабом, даже среднем нашествиях.

Из числа подвергаемых исследованию мест проверялось всегда 30 штук рыб. Обследование было проведено паразитологическим вскрытием рыб и выявленное нашествие было выражено абсолютным числом паразитов.

У образцов, отобранных 10 августа 1976 г., месяца два после рождения рыб, была установлена $20 \%$ экстенсивность наличия, при интенсивности 1 взрослый гельминт или личинка у одной рыбы. У образца, отобранного 6 сентрября 1976 г. экстенсивность нашествий дошла до $70 \%$, при средней экстенсивности 2,5 гельминтов. Максимальная интенсивность достигала 7 гельминтов.

Работа занимается видовым определением исследуемого материала с одновременным использованием действительных критериев для видового различения индивидов данного рода.

Гельминты достигали 2,6-3,1 мм величины, длина их передней части составляла 1,7-2,08 мм, задней части - 0,78-1,4 мм. Диаметр передней и задней частей тела достигал 2-2,17:1. Ширина метаморфированных присосок достигала $0,099-0,156$ мм. Черешок средних зацепок достигает длины 0,041-0,047 мм, собственная зацепка - 0,018--0,022 мм, длина кончика 0,006 мм. После тщательного изучения специальной литературы было уста- 
новлено, что все исследуемые экземпляры принадлежали виду Diplozoon homoin, который является частым паразитом карповых рыб (Rutilus rutilus, Carassius carassius, Leuciscus cephalus, Alburnus alburnus).

Вид Hypophthalmichthys molitrix является новым хозяином моногенетической двуустки Diplozoon homoin и приведенные карловые виды рыб, считатемые в системах прудов сорными рыбами, необходимо считать резервуарами данного вида паразита для племенных видов - белый толстолобик, который интенсивно разводитсь в наблюдаемом рыбопитомнике.

\section{References}

ACHMEROF, A.: Novije vidy Diplozoon ryb reky Amur. Trudy gelmintologičeskoj laboratorii, XXIV, 1974: 5-19.

BYCHOWSKI et al.: Opredělitel parazitov presnovodnych ryb SSSR. Moskva-Leningrad, 1962: $776 \mathrm{pp}$.

ERGENS, R. - LOM, J.: Původci parazitárních nemocí ryb. Praha, 1970: 383 pp.

NAGIBINA, L.: Novije vidy roda Diplozoon (Discocotylidae, Monogenoidea). Trudy zoologičeskovo instituta, XXXV, 1965: 167-174.

PEJCOCH, M.: Beitrag zur Kenntnis der Gattung Diplóżoon Nordmann, 1832 (Monogenoidea). Spisy přírodov. fak. J. E. Purkyně v Brně, 497, 1968: 373-398.

PEJCOCH, M.: Eine UUbersicht der Arten der Gattung Diplozoon Nordmann, 1832 (Discocotylidae, Monogenoidea). Scripta Fac. nat. UJEP Brunensis, Biologia 5, 4, 1974: 171-178. 